\title{
Perceptions of Pre-school Teachers in Terms of Music Culture*
}

\author{
Berna Özkut ${ }^{1, *}$, Saibe Özlem Kaya ${ }^{2}$ \\ ${ }^{1}$ Department of Performing Arts, State Conservatory, Afyon Kocatepe University, Turkey \\ ${ }^{2}$ Basic Education Department, Faculty of Education, Afyon Kocatepe University, Turkey
}

Copyright $(2019$ by authors, all rights reserved. Authors agree that this article remains permanently open access under the terms of the Creative Commons Attribution License 4.0 International License

\begin{abstract}
The aim of this research is to reveal the accumulation of musical culture of preschool teachers and to get their viewpoints about music culture. The sub-objectives of the research are consisted of finding answers to "To what extent pre-school teachers support the music activities in the city where they work", "how often they participate in these music activities", "what it means to have music culture accumulation in their individual life and educational life". This research was conducted with a survey model and the sample of the research constitutes 221 pre-school teachers studying in Afyonkarahisar city center while its sample is consisted of 55 preschool teachers. The questionnaire was applied to the pre-school teachers who were selected as the sampling in terms of determining their views about music culture and accumulation of their music culture. The data gained from this study was analyzed by a package program named as IBM SPSS statistics version 20. While investigating the relationships among the nominal variable groups, chi-square analysis was performed. On the condition that the expected values in the entries of the $2 * 2$ tables did not have the sufficient volume, Fisher's exact test was used, while in the $\mathrm{RxC}$ tables Pearson chi-square analysis was performed with the help of Monte Carlo Simulation. Thus, the existing situation has been determined and what it should be has been found out. This music culture survey involves questions such as "How the pre-school teachers' musical education in the undergraduate study period affects their musical cultures", "What kind of music they listen", "At what level they follow the music activities" and "How musical cultures influence their professional areas and their general life". This study sheds light on the fact that it is necessary to propose and improve the preschool education program in pre-school teacher education period in terms of music culture and music education, and has fundamental aspects in relation to being a source for the future studies on music culture.
\end{abstract}

Keywords Preschool Teacher, Music, Music Culture

\section{Introduction}

Culture is defined as all of the products created by people or a community in material and spiritual fields; all kinds of tools used to obtain basic needs such as food, clothing, shelter, refuge and applied techniques; ideas, information, beliefs; traditional, religious, social and political order and institutions; thoughts, perception, attitudes, all forms of behavior; way of life [1]. Culture is the total combination of material and spirituality that is a produced by human community through its communication with the natural and social environment. That is to say, culture is the total of the thoughts, attitudes and behavior that direct various objects of the natural and social environment and the interactions among the people in this environment. Through a general definition, we can describe culture as a complicated unity containing habits, knowledge, art, morals, traditions and customs acquired as a part of society as well as referring to it as, in fact, the embodiment of a religion belonging to any society. In other words, culture can also be described as "something that makes life worth living" [2].

Perhaps one of the most important factors that make up culture is the art and the music, which is one of the branches of culture, bears the traces of the culture in which it was formed, developed and experienced. The following definition that "Art is the concrete and shaped forms of society cultures" provides the idea that art is the language facing towards social structure [3].

Music art is an integral part of all cultures from the most primitive to the most developed societies. According to Say, 'Music is a language that allows people to express their emotions, thoughts via voice [4]. "Music is a cultural phenomenon. It directly influences the formation and shaping of cultures. It establishes links between past and future and verbalizes the 'human being' that is both the cause and the result of that culture and values of humans" 
[5]. Art exists so as to give strength to humanity. Art lives to create an area of occupation that sheds light on the logic oriented environment in which man lives and develops reasonably in spiritual direction. Because of pure existence, art prevails to function as a tool that affects the way people look at life, which wraps their senses and turns their emotions into motions. Art stands out so as to ensure the balances in human life [6].

One of the most important branches of art in the continuity of cultures is the music itself. Music is an aesthetic whole that expresses thoughts, impressions and designs, and as well as certain situations, phenomena and events with the contribution of other facts; combining according to a certain sense of beauty with a certain purpose and method, processing and conveying with formatted voices. Music is the only one language that everyone can and will understand [7].

Music is a culture of expression that takes place in and around every step of human life. Some people position music in their life in the field of listening, some put it in to entertainment place while some regard it as an intellectual behavior and some take it as a leisure time activity. Therefore, music represents a profound and indispensable domain for human life in almost every society. Music production (composing, sounding) and consumption (listening, watching) activity come out as a result of aesthetic choice and cultural judgment. Aesthetic values are complex, holistic phenomenon that are systematized by socio-cultural means and are made meaningful within this systematic. Music on the axis of these phenomena helps us to shape our feelings, ourselves, our gender, our bodies, our pleasures and even ideas we have internalized about our social organization [8]."Music, since the existence of mankind, feeds the individuals and the societies." Music culture, with people- the main source of it - in the process of evolution, displays a variable and transformative property sometimes fast, sometimes slow, but continuously evolving." [9]. Music is not just a source of inspiration for big music masters. Even a newly born baby moves his hands and arms with rhythmic movements. According to that, music can be defined as the common language of all arts that ensure the link between different reflections of the universal beauty in the world with which everyone has fallen in love [10].It is accepted that it is the art of music, which gives the deepest effect on the human soul in all branches of art. Since music is a universal language that extends from man to man and has the power to unite people from different origins and languages in the same melody, these facts have given music a distinctive place among the other art branches, granting a certain privilege [11].

Music culture is a complicated unity that covers knowledge, skills, attitudes and behaviors related to the art of music that human beings gain in addition to general culture along with code of ethics, traditions and other similar skills and habits valid in music environments [12].In the formation of music culture, an individual's music preference and liking are also important. The individuals, who love to listen to music but do not consciously have a music culture and who do not/ cannot use this music culture in their daily life and academic field cannot understand and perceive music sufficiently. Already, music is not just for entertainment or for listening. It is in a state of being intertwined with culture. There is no culture without its language, nor is there culture without music. Although music seems to be a natural thing, a phenomenon that exists on its own, but with human values, it is full with feelings indicating what is good, what is bad, what is right, what is wrong. Music is not a thing of its own, rather it is an important part of individuals and by which individuals add meaning to their culture. People think with music and express themselves with music [13].

In today's society, it is accepted that there is mass music culture as an integral part of mass culture. The understanding of musical culture is a multi-faceted and multi-dimensional comprehension in itself. The first few things that come to mind when recall music culture are the folk music, polyphonic western music, popular music, choral music, instrumental music, theory-form information and so on. In addition to these, attention is paid to the aims of music culture, such as its role in social life, role in individual education, etc. [14]. An individual's music preference and liking are also important in the formation of his music culture. [15] lists the factors that affect the music preference and liking of the individual as follows:

- Individual factors: The state of listening that describes age, gender, ethnicity, personality and psychological state of person - Social Factors: It classifies as social class, family, peers, enculturation, media and reputation effect.

These factors are in constant interaction with each other and the effects on individuals or societies are also disparate. In addition, they are all like complementary to each other and are considered as a whole. Within this complex structure, music culture continues to exist as a far-reaching part of the culture in which people live, depending on many variables. Music culture is seen as a vast sea in terms of the breadth of its covering content. However, if music culture is viewed from a broader perspective, there is a certain social view. In the creation of an advanced society, music culture and music education should be given great importance for modernization [16].

Since Music is the most important element of human education, music culture should not be ignored as the pre-school teacher candidates pass through an effective and efficient education process. Thus, their musical culture accumulations will firstly be a useful tool for their own lives and then for their future professional life. Music education should be given a place as a lesson in the school education program in education faculties. As a result, it can be ensured that preschool teacher candidates also live and use their musical experiences consciously. At the same time, an educator's point of view on music art reflects his point of view on his life. Therefore, music education and 
music culture should be attached sufficient importance for all prospective teachers in education faculties. This study is important because it is a resource providing guidance and it is particularly important to inform the teacher education institutions about the extent to which art education is applied. Teachers with musical cultures will raise well-equipped generations in cultural sense. This will increase the level of music and culture of the society. Based on this literature, "What are the viewpoints of the preschool teachers studying in Afyonkarahisar city center concerning their music culture?" makes the problem of this study. Within the framework of the identified problem, the sub-problems of the research are listed as follows:

1. How are pre-school teachers' musical culture accumulations?

2. What are pre-school teachers' perceptions on musical cultures?

3. How do pre-school teachers use their musical culture accumulations when they apply their subject field?

4. How did pre-school teachers' undergraduate education affect their music culture accumulations?

5. What are the levels of pre-school teachers in practicing music culture accumulations in their professional lives?

6. How do the cultural environment in which pre-school teachers are located influence their musical culture?

7. Are there any significant differences among teachers' perceptions based on "education level and seniority"?

\section{Methodology}

This study was conducted within a mixed model. The first part of the study was conducted with a survey method adapting a descriptive research model. Second part of the study was conducted via qualitative research method and open ended questions were asked to the participants. One of these questions is" What are the viewpoints of the preschool teachers studying in Afyonkarahisar city center concerning the music culture?" As a sample, the preschool teachers in selected schools in Afyonkarahisar province center have been identified. To determine their viewpoints on music cultures and their practice level in their field of music culture accumulation, a questionnaire form was used that encompasses a total of 28 questions involving 27 multiple choice questions and 1 open ended question. The questionnaire, which is an instrument of music culture measurement was developed by Arabac1 [17] in her master thesis named as "Opinions of Different Field Teachers Duties in Şereflikoçhisar and Evren Regions Regarding Music Cultures". Thus, that the existing state and what it has to be was determined, and suggestions were also made on the emerging results.

\section{The Sample}

The sample of the research is composed of preschool teachers working in the schools in Afyonkarahisar city and the sample is consisted of 55 preschool teachers working in 14 different schools.

The population of the research constitutes 221 pre-school teachers studying in Afyonkarahisar city center while its sample is consisted of 55 preschool teachers.

\section{Data Collection and its Analysis}

In order to collect data related to the study, a questionnaire was applied to the study group developed by Arabac1 [17] named as an instrument of music culture measurement(a total of 28 questions involving 27 multiple choice questions and 1 open ended question). In this study, the data obtained by the questionnaire were analyzed with the SPSS Statistics Version 20 statistical package program. In the examination of the relations between groups of nominal variables, Chi-square analysis was applied. On the condition that the expected values in the entries of the $2 * 2$ tables did not have the sufficient volume, Fisher's exact test was used. Also, Pearson chi-square analysis was performed in the RxC tables with the help of Monte Carlo Simulation.

\section{Findings}

\subsection{Findings related to personal information}

In this section, it was aimed to determine the specific personal qualities of the preschool teachers who constitute the research group. Based on the demographic results, 1.1, $87,27 \%$ of the preschool teachers constituting the research group are females while $12,73 \%$ of the preschool teachers were found to be males and preschool teachers constituting the research group are college graduates and $90 \%$ of the preschool teachers are university graduates. In addition, it is understood that $1.82 \%$ of the preschool teachers are master students whereas $1.82 \%$ of them have received $\mathrm{Ph}$. D. level education. This result shows that the vast majority of teachers participating in the survey are university graduates.

Moreover, 21,81\% of the preschool teachers who constitute the research group have a professional service period between $0-5$ years while $49,09 \%$ of the preschool teachers are between 6 and 10 professional service periods. In addition, $12,73 \%$ of the preschool teachers have a professional service period between 11 and 15 years whereas $16,36 \%$ of the preschool teachers possess a professional service period between 16 and 20 years. This shows that the majority of teachers who responded to the survey could be regarded as new to their profession since they are between 6-10 years or 0-5 years. Therefore, when it is thought that the majority of respondents are young 
teachers, it may be concluded that they responded the survey according to the curriculum they received during the undergraduate study period. Thus, in the direction of the data obtained as a result of the survey, it may be commented that in the field of preschool education in education faculties there is still a need to make new arrangements and changes in the music education course in the curricula that are still in practice. In addition, $49,09 \%$ of the preschool teachers who constitute the research group work in the State School and 50,91\% of the preschool teachers work in the State School-Independent Kindergarten. It is observed that the preschool teachers' distributions by their institutions are balanced.

\subsection{Preschool Teachers' Views on their Music Culture Accumulation}

This section includes findings that define the views, suggestions and approaches of teachers on having musical cultural accumulation and these findings were intended to be explained and interpreted.

Table 1. Distribution of Accumulation of Musical Culture of Preschool Teachers in Their General Cultures

\begin{tabular}{|c|c|c|}
\hline & $\mathbf{n}$ & $\mathbf{\%}$ \\
\hline Completely & 5 & 9,09 \\
\hline Highly & 14 & 25,45 \\
\hline Partially & 32 & 58,18 \\
\hline Very little & 4 & 7,27 \\
\hline No & - & - \\
\hline Total & 55 & 100 \\
\hline
\end{tabular}

As it is shown in Table.1, pre-school teachers stated that they have a large amount of music culture accumulation with $25.45 \%$ while those indicated that they partially have a music culture accumulation with $58.18 \%$. The last option of "no" has been left blank and unchecked. As for this situation, it can be said that most of the teachers think that they have a certain musical culture within their general cultures even if it is partial. However, the quality of this musical culture accumulation should be considered according to what extent they have been educated in the general cultural dimension during the undergraduate education period.

Table 2. Distribution of the Level of Preschool Teachers Musical Culture Accumulation

\begin{tabular}{|c|c|c|}
\hline & $\mathbf{n}$ & $\mathbf{\%}$ \\
\hline Completely & 5 & 9,09 \\
\hline Highly & 13 & 23,64 \\
\hline Partially & 33 & 60 \\
\hline Very little & 4 & 7,27 \\
\hline No & - & - \\
\hline Total & 55 & 100 \\
\hline
\end{tabular}

As it is seen in Table.2, pre-school teachers stated that they partially have music culture accumulation with $60 \%$, highly with $23.64 \%$, completely with $9.09 \%$, very little with $7.27 \%$. The last option has been left unchecked. The study reveals that teachers think that they have a certain amount of music culture accumulation even if it is partial.

Table 3. Distribution of the Dimensions as Preschool Teachers Consider Their Musical Culture Accumulation

\begin{tabular}{|c|c|c|}
\hline & $\mathbf{n}$ & $\mathbf{\%}$ \\
\hline Artistic dimension & 17 & 30,91 \\
\hline Scientific dimensions & 3 & 5,45 \\
\hline $\begin{array}{c}\text { Entertainment } \\
\text { dimension }\end{array}$ & 30 & 54,55 \\
\hline Other dimensions & 5 & 9,09 \\
\hline Total & 55 & 100 \\
\hline
\end{tabular}

As it can be observed in Table.3, pre-school teachers indicated that they regarded it as a musical entertainment medium with $54,55 \%$ and they considered it as artistic with $30,91 \%$. It is not a positive situation for preschool teachers to regard music as merely an entertainment medium. Music is not just for fun and listening. It is in a state of being intertwined with culture. In this scope, it can commented that in addition to music education provided to preschool teacher candidates in their undergraduate education period. If they participate in workshops about music culture, conferences and in-service trainings on music culture, and music education and take part in activities such as courses, this situation can change their perspectives in a more qualified and conscious way in terms of their musical culture.

Table 4. Distribution of viewpoints of Preschool Teachers on to what extent having Adequate Music Cultural influences their general life

\begin{tabular}{|c|c|c|}
\hline & $\mathbf{n}$ & \% \\
\hline Completely & 8 & 14,55 \\
\hline Highly & 27 & 49,09 \\
\hline Partially & 20 & 36,36 \\
\hline Very little & - & - \\
\hline No & - & 100 \\
\hline Total & 55 & \\
\hline
\end{tabular}

As it is displayed in Table.4, pre-school teachers stated that having adequate musical culture is highly influential on the general life behavior of the individual with $49,09 \%$ and partially effective on them with $36,36 \%$ while it was found as completely influential on them with $14.55 \%$. In this case, the majority of teachers are of the opinion that having musical cultures significantly affects the general life of the individual. Also, the "very little" and "no" options are left blank and unmarked. 
Table 5. Distribution of level of Preschool Teachers' Conscious Use of Information in their life Based on Music Cultural

\begin{tabular}{|c|c|c|}
\hline & $\mathbf{n}$ & $\mathbf{\%}$ \\
\hline Completely & - & - \\
\hline Highly & 18 & 32,73 \\
\hline Partially & 27 & 49,09 \\
\hline Very little & 6 & 10,91 \\
\hline No & 4 & 7.27 \\
\hline Total & 55 & 100 \\
\hline
\end{tabular}

As seen in Table.5, the pre-school teachers responded to that question partially with $49,09 \%$, highly with $32,73 \%$, very little with $10,91 \%$ and no with $7,27 \%$, respectively. For that reason, it appears that preschool teachers use their music culture accumulations they have partly in their lives whereas it has emerged that school-teachers cannot use their music culture accumulations qualitatively and consciously in their lives. Also, the "completely" option is not marked and has been left blank.

Table 6. Distribution of viewpoints of Preschool Teachers in terms of Importance of music in the life of the individual

\begin{tabular}{|c|c|c|}
\hline & $\mathrm{n}$ & $\%$ \\
\hline Completely & 8 & 14,55 \\
\hline Highly & 27 & 49,09 \\
\hline Partially & 20 & 36,36 \\
\hline Very little & - & - \\
\hline No & - & - \\
\hline Total & 55 & 100 \\
\hline
\end{tabular}

According to the table in Table.6; 49,09\% of the pre-school teachers participating in the survey mentioned that music is an important part of the individual's life while $36,36 \%$ of the pre-school teachers believed it is partially important and $14,55 \%$ of the pre-school teachers indicated that music is completely important. Thus, it may be concluded for a large majority of preschool teachers that they are aware that music has an important place in the individual's life. This is a positive result in Awareness dimension.

Table 7. Distribution of the Types of Music the Preschool Teachers Listen

\begin{tabular}{|c|c|c|}
\hline & $\mathbf{n}$ & $\mathbf{\%}$ \\
\hline Classical Western Music & 9 & 16,36 \\
\hline Turkish Folk Music & 38 & 69,09 \\
\hline Turkish Art Music & 27 & 49,09 \\
\hline Foreign Pop & 8 & 14,55 \\
\hline Turkish Pop & 31 & 56,36 \\
\hline Jazz & 3 & 5,45 \\
\hline New Age & 2 & 3,64 \\
\hline
\end{tabular}

*More than one answer option has been marked.
It is clear that jazz, new age and classical western music are not preferred much. In this context, to introduce the preschool teachers with universal music genres in addition to the music of our own culture, in-service training seminars, concerts and workshops can be organized through university - national education and university - city cooperation.

Table 8. Distribution of Musical Activities by Preschool Teachers during Undergraduate Education

\begin{tabular}{|c|c|c|}
\hline & $\mathbf{n}$ & $\mathbf{\%}$ \\
\hline As audience & 40 & 72,73 \\
\hline Joining a chorus & 5 & 9,09 \\
\hline $\begin{array}{c}\text { By playing the } \\
\text { instrument }\end{array}$ & 5 & 9,09 \\
\hline Other & 5 & 9,09 \\
\hline Total & 55 & 100 \\
\hline
\end{tabular}

As it is seen in Table.8; preschool teachers stated that they attended to music activities as audience with $72,73 \%$ in their undergraduate education. The individuals who love to listen to music but do not consciously have a music culture and who do not/cannot use this music culture in their daily life and academic field cannot understand and perceive music sufficiently. As a matter of fact, music is not just for listening. Music is not a thing of its own. On the other hand, it is an important part of culture and it is something to which individuals add meaning. Therefore, musical activities related to musical culture and related media during the undergraduate education period should be presented to the preschool teacher candidates more and in a more qualified way. In this context, the above table also shows the lack and weakness of these environments.

Table 9. Distribution by the Degree of Influence of Undergraduate Education on Preschool Teachers' Music Culture Accumulation

\begin{tabular}{|c|c|c|}
\hline & $\mathbf{n}$ & \% \\
\hline Completely & 3 & 5,45 \\
\hline Highly & 4 & 7,27 \\
\hline Partially & 23 & 41,82 \\
\hline Very little & 22 & 40 \\
\hline No & 3 & 5,45 \\
\hline Total & 55 & 100 \\
\hline
\end{tabular}

As it is noticed in Table.9; it is clear that the degree of influence of undergraduate education on preschool teachers' musical culture has been partially and very little.

Table 10. Whether the Preschool Teachers Have Taken Music Culture Course in Undergraduate Education Period

\begin{tabular}{|c|c|c|}
\hline & $\mathbf{n}$ & $\mathbf{\%}$ \\
\hline Yes & 17 & 30,91 \\
\hline No & 38 & 69,09 \\
\hline Total & 55 & 100 \\
\hline
\end{tabular}

As it is observed in Table.10, it is found out that the 
music education of the preschool teachers is inadequate in terms of teaching hours and contents of course in undergraduate education period and it is clearly shortcoming that undergraduate education lacks music culture. In this context, preschool curricula at universities can be reviewed and regulated.

Table 11. Whether the Preschool Teachers Have Taken Music Education in Undergraduate Education Period

\begin{tabular}{|c|c|c|}
\hline & $\mathbf{n}$ & $\mathbf{\%}$ \\
\hline Yes & 50 & 90,91 \\
\hline No & 5 & 9,09 \\
\hline Total & 55 & 100 \\
\hline
\end{tabular}

Table.11shows that the preschool teachers have taken the music education course in their undergraduate education with yes option with $90,91 \%$.

Table 12. Distribution of the Music Education of the Preschool Teachers in Their Undergraduate Education Period

\begin{tabular}{|c|c|c|}
\hline Education Distribution & $\mathbf{n}$ & $\mathbf{\%}$ \\
\hline Only Theoretical & 27 & 54,00 \\
\hline Musical Note & 13 & 26,00 \\
\hline Block Flute & 27 & 54,00 \\
\hline General & 6 & 12,00 \\
\hline Instrument Education & 3 & 6,00 \\
\hline Turkish Folk Music (THM) & - & - \\
\hline History of Music & 2 & 4,00 \\
\hline Music Concert & 1 & 2,00 \\
\hline
\end{tabular}

*More than one answer option is marked.

As the table.12 shows, it is seen that the pre-school teachers who participated in the study received only theoretical education in the music education course with 54\% and $54 \%$ of pre-school teachers received block flute education. It can be said that in this case, music education courses at universities for preschool teachers should not be limited to two terms and qualified changes and arrangements should be made.

Table 13. Distribution Showing How Prospective Preschool Teachers' Perspectives on Music Culture in Education Faculties May Change After Taking Courses Related to Music

\begin{tabular}{|c|c|c|}
\hline & $\mathbf{n}$ & $\mathbf{\%}$ \\
\hline Completely & 6 & 10,91 \\
\hline Highly & 30 & 54,55 \\
\hline Partially & 16 & 29,09 \\
\hline Very little & 2 & 3,64 \\
\hline No & 1 & 1,82 \\
\hline Total & 55 & 100 \\
\hline
\end{tabular}

According to Table.13, the pre-school teachers who participated in the study agree on the idea that taking courses related to music in their undergraduate education will Highly develop their musical cultures with 54,55\%, partially with $29,09 \%$, completely with $10,91 \%$, respectively. This result is actually a positive result in awareness dimension.

Table 14. Preschool Teachers' Participation in Musical Activities in Afyonkarahisar Province Center

\begin{tabular}{|c|c|c|}
\hline & $\mathbf{n}$ & $\mathbf{\%}$ \\
\hline Completely & - & - \\
\hline Highly & 4 & 7,27 \\
\hline Partially & 22 & 40 \\
\hline Very little/few & 17 & 30,91 \\
\hline No & 12 & 21,82 \\
\hline Total & 55 & 100 \\
\hline
\end{tabular}

As it is noticed in Table.14, it is seen that most of the preschool teachers who participated in the study cannot take part in the music events happening in Afyonkarahisar. The pre-school teachers responded to that question with $21.82 \%$ with no option, $30.91 \%$ with very few option and $40 \%$ with partially option, respectively. In this case, in-service training courses and activities should be increased in the city center where the pre-school teachers work and musical activities related to music culture should be held in cooperation with the city and university. In this context, it is necessary for municipalities, governorships, provincial directorate of national education, teachers' institutions and universities to carry out great duties.

Table 15. Distribution by Contributions of the City to the Cultural Accumulations of the Preschool Teachers

\begin{tabular}{|c|c|c|}
\hline & $\mathbf{n}$ & $\mathbf{\%}$ \\
\hline Completely & - & - \\
\hline Highly & 4 & 7,27 \\
\hline Partially & 27 & 49,09 \\
\hline Very little & 19 & 34,55 \\
\hline No & 5 & 9,09 \\
\hline Total & 55 & 100 \\
\hline
\end{tabular}

As it can be noticed in Table .15, preschool teachers believed that the city in which they work make contribution partially with $49,09 \%$, very little with $34,55 \%$ and no with $9,09 \%$, respectively. This state suggests that the available opportunities in Afyonkarahisar province center for teachers to develop their musical culture accumulations are partially sufficient.

Table 16. Distribution of views of Preschool Teachers on to what extent they find the events adequate held in their city

\begin{tabular}{|c|c|c|}
\hline & n & \% \\
\hline Completely & - & - \\
\hline Highly & 4 & 7,27 \\
\hline Partially & 26 & 47,27 \\
\hline Very little/few & 21 & 38,18 \\
\hline No & 4 & 7,27 \\
\hline Total & 55 & 100 \\
\hline
\end{tabular}


According to the Table.16, the pre-school teachers regard the music activities held in the city where they work partially adequate with $47.27 \%$ and very few with $38.18 \%$. it can be concluded in this case that the music activities organized in Afyonkarahisar city center are partially sufficient.

Table 17. Views of Preschool Teachers on to what extent they support Music Activities located in Social Activities

\begin{tabular}{|c|c|c|}
\hline & $\mathbf{n}$ & $\mathbf{\%}$ \\
\hline Completely & 11 & 20 \\
\hline Highly & 34 & 61,82 \\
\hline Partially & 6 & 10,91 \\
\hline Very little & 3 & 5,45 \\
\hline No & 1 & 1,82 \\
\hline Total & 55 & 100 \\
\hline
\end{tabular}

As it can be observed in Table .17, the pre-school teachers stated that they highly support musical activities with $61,82 \%$ and completelywith $20 \%$ and partially with $10,91 \%$, respectively.

Table 18. Status of Preschool Teachers to Obtain Music-Related Publications

\begin{tabular}{|c|c|c|}
\hline & $\mathbf{n}$ & $\mathbf{\%}$ \\
\hline Completely & - & - \\
\hline Highly & 5 & 9,09 \\
\hline Partially & 19 & 34,55 \\
\hline Very little & 19 & 34,55 \\
\hline No & 12 & 21,82 \\
\hline Total & 55 & 100 \\
\hline
\end{tabular}

Table.18 displays that the pre-school teachers who participated in the research have obtained music publications. 2 with a very low rate of $34,55 \%$ and $34.55 \%$. It is possible to say from the gained findings that almost half of the pre-school teachers participated in the study have very few chances of acquiring music-related publications. In this scope, music seminars and activities to introduce related publications in Afyonkarahisar province should be performed for preschool teachers. Besides, archives including music-related publications can be provided by school administrators, which may serve as qualified resource. Such publications can be included in the Afyonkarahisar provincial library, which can make teachers well-equipped about music education and culture.

Table 19. Ownership Status of Preschool Teachers of Music CD-DVD and / or Record Archives

\begin{tabular}{|c|c|c|}
\hline & $\mathbf{n}$ & $\mathbf{\%}$ \\
\hline Completely & - & - \\
\hline Highly & 11 & 20 \\
\hline Partially & 15 & 27,27 \\
\hline Very little/few & 24 & 43,64 \\
\hline No & 5 & 9,09 \\
\hline Total & 55 & 100 \\
\hline
\end{tabular}

The Table above mentions that $43,64 \%$ of the preschool teachers who participated in the study stated that they have very few music-related CD-DVD and / or record archives while $27.27 \%$ of the preschool teachers informed that they Partially have music-related CD-DVD and / or record archives. According to data obtained, it can be concluded that the teachers do not have a qualified and adequate music archive. As we go through this Table, it was determined that the pre-school teachers failed to realize the importance of creating a music archive.

Table 20. Importance of Cultural Accumulation of Music in Contemporary Teacher Model According to Preschool Teachers

\begin{tabular}{|c|c|c|}
\hline & $\mathbf{n}$ & $\mathbf{\%}$ \\
\hline Completely & 12 & 21,82 \\
\hline Highly & 32 & 58,18 \\
\hline Partially & 10 & 18,18 \\
\hline Verylittle/few & 1 & 1,82 \\
\hline No & 55 & 100 \\
\hline Total & 12 & 21,82 \\
\hline
\end{tabular}

As seen in Table.20, it can be said that teachers are aware of the importance of having musical culture accumulations as educators according to the obtained data.

Table 21. Preschool Teachers' Views about the Effect of Having Sufficient Musical Culture Accumulations on Their Subject Areas

\begin{tabular}{|c|c|c|}
\hline & $\mathbf{n}$ & \% \\
\hline Completely & 8 & 14,55 \\
\hline Highly & 32 & 58,18 \\
\hline Partially & 14 & 25,45 \\
\hline Verylittle/few & 1 & 1,82 \\
\hline No & 55 & 100 \\
\hline Total & 8 & 14,55 \\
\hline
\end{tabular}

As it may be seen in Table.21, it can be commented according to the obtained data that in-service training seminars can be organized in order for the preschool teachers to have a qualified musical culture and use their musical culture in their own subject field.

Table 22. Views of Preschool Teachers towards Using their Music Culture Accumulation as a Tool in Their Fields

\begin{tabular}{|c|c|c|}
\hline & $\mathrm{n}$ & $\%$ \\
\hline Completely & 6 & 10,91 \\
\hline Highly & 17 & 30,91 \\
\hline Partially & 18 & 32,73 \\
\hline Very little & 13 & 23,64 \\
\hline No & 1 & 1,82 \\
\hline Total & 55 & 100 \\
\hline
\end{tabular}

As it may be recognized in Table.22, the preschool teachers stated that they never use music culture accumulation in their fields with $36.78 \%$ and use it very 
little with $24.13 \%$. 1t was determined that the majority of the teachers did not consciously put the musical knowledge into practice in their own fields.

\subsection{Findings and Interpretations about the Eighth Subordinate Problem of the Study}

The eighth subordinate problem of the study has been determined and it is as follows:

Are there any significant differences among teachers' perceptions based on "gender, education level, seniority in the profession and place of work" variables?

Table 23. Chi Square Test Results on Relation between Variables Related to Education Level and Music Culture Accumulation

\begin{tabular}{|c|c|c|c|c|c|c|c|c|c|c|c|}
\hline & & \multicolumn{8}{|c|}{ Education Level } & \multirow{2}{*}{\multicolumn{2}{|c|}{$\begin{array}{c}\text { Chi Square } \\
\text { Test }\end{array}$}} \\
\hline & & \multicolumn{2}{|c|}{ College graduate } & \multicolumn{2}{|c|}{ University graduate } & \multicolumn{2}{|c|}{ Master / PhD } & \multicolumn{2}{|c|}{ Total } & & \\
\hline & & $\mathrm{n}$ & $\%$ & $\mathrm{n}$ & $\%$ & $\mathrm{n}$ & $\%$ & $\mathrm{n}$ & $\%$ & $\begin{array}{c}\mathrm{Ki} \\
\text { Kare }\end{array}$ & $\mathrm{p}$ \\
\hline \multirow{5}{*}{$\begin{array}{l}\text { As you evaluate it in your } \\
\text { general culture, what is the } \\
\text { position of your music } \\
\text { culture accumulation? }\end{array}$} & Completely & 0 & 0 & 4 & 8 & 1 & 50 & 5 & 9,09 & \multirow{5}{*}{$*$} & \multirow{5}{*}{0,192} \\
\hline & Highly & 0 & 0 & 14 & 28 & 0 & 0 & 14 & 25,45 & & \\
\hline & Partially & 2 & 66,67 & 29 & 58 & 1 & 50 & 32 & 58,18 & & \\
\hline & Very little/few & 1 & 33,33 & 3 & 6 & 0 & 0 & 4 & 7,27 & & \\
\hline & Total & 3 & 100 & 50 & 100 & 2 & 100 & 55 & 100 & & \\
\hline \multirow{5}{*}{$\begin{array}{c}\text { To what extent do you think } \\
\text { you have music culture } \\
\text { accumulation? }\end{array}$} & Completely & 0 & 0 & 4 & 8 & 1 & 50 & 5 & 9,09 & \multirow{5}{*}{$*$} & \multirow{5}{*}{0,213} \\
\hline & Highly & 0 & 0 & 13 & 26 & 0 & 0 & 13 & 23,64 & & \\
\hline & Partially & 2 & 66,67 & 30 & 60 & 1 & 50 & 33 & 60 & & \\
\hline & Very little/few & 1 & 33,33 & 3 & 6 & 0 & 0 & 4 & 7,27 & & \\
\hline & Total & 3 & 100 & 50 & 100 & 2 & 100 & 55 & 100 & & \\
\hline \multirow{5}{*}{$\begin{array}{c}\text { In which dimension do you } \\
\text { evaluate your music culture } \\
\text { accumulations more? }\end{array}$} & As an audience & 1 & 33,33 & 15 & 30 & 1 & 50 & 17 & 30,91 & \multirow{5}{*}{$*$} & \multirow{5}{*}{1} \\
\hline & Joining a chorus & 0 & 0 & 3 & 6 & 0 & 0 & 3 & 5,45 & & \\
\hline & Instrument playing & 2 & 66,67 & 27 & 54 & 1 & 50 & 30 & 54,55 & & \\
\hline & Other & 0 & 0 & 5 & 10 & 0 & 0 & 5 & 9,09 & & \\
\hline & Total & 3 & 100 & 50 & 100 & 2 & 100 & 55 & 100 & & \\
\hline \multirow{4}{*}{\begin{tabular}{|c|} 
To what extent do you \\
believe that the behavior of \\
an individual with enough \\
musical cultures affects his \\
or her overall life \\
experience?
\end{tabular}} & Completely & 1 & 33,33 & 6 & 12 & 1 & 50 & 8 & 14,55 & \multirow{4}{*}{$*$} & \multirow{4}{*}{0,408} \\
\hline & Highly & 1 & 33,33 & 26 & 52 & 0 & 0 & 27 & 49,09 & & \\
\hline & Partially & 1 & 33,33 & 18 & 36 & 1 & 50 & 20 & 36,36 & & \\
\hline & Total & 3 & 100 & 50 & 100 & 2 & 100 & 55 & 100 & & \\
\hline \multirow{5}{*}{$\begin{array}{c}\text { Do you consciously use } \\
\text { your knowledge in your life } \\
\text { based on your music } \\
\text { culture? }\end{array}$} & Completely & 1 & 33,33 & 2 & 4 & 1 & 50 & 4 & 7,27 & \multirow{5}{*}{$*$} & \multirow{5}{*}{0,058} \\
\hline & Highly & 1 & 33,33 & 17 & 34 & 0 & 0 & 18 & 32,73 & & \\
\hline & Partially & 0 & 0 & 26 & 52 & 1 & 50 & 27 & 49,09 & & \\
\hline & Very little/few & 1 & 33,33 & 5 & 10 & 0 & 0 & 6 & 10,91 & & \\
\hline & Total & 3 & 100 & 50 & 100 & 2 & 100 & 55 & 100 & & \\
\hline \multirow{4}{*}{$\begin{array}{l}\text { To what extent do you think } \\
\text { music is important in an } \\
\text { individual's life? }\end{array}$} & Completely & 1 & 33,33 & 6 & 12 & 1 & 50 & 8 & 14,55 & & \\
\hline & Highly & 1 & 33,33 & 26 & 52 & 0 & 0 & 27 & 49,09 & * & 0408 \\
\hline & Partially & 1 & 33,33 & 18 & 36 & 1 & 50 & 20 & 36,36 & & 0,408 \\
\hline & Total & 3 & 100 & 50 & 100 & 2 & 100 & 55 & 100 & & \\
\hline & As an audience & 1 & 33,33 & 38 & 76 & 1 & 50 & 40 & 72,73 & & \\
\hline Which musical activities & Joining a chorus & 0 & 0 & 5 & 10 & 0 & 0 & 5 & 9,09 & & \\
\hline were you involved in during & Instrument playing & 0 & 0 & 4 & 8 & 1 & 50 & 5 & 9,09 & $*$ & 0,047 \\
\hline your undergraduate studies? & Other & 2 & 66,67 & 3 & 6 & 0 & 0 & 5 & 9,09 & & \\
\hline & Total & 3 & 100 & 50 & 100 & 2 & 100 & 55 & 100 & & \\
\hline & Completely & 0 & 0 & 2 & 4 & 1 & 50 & 3 & 5,45 & & \\
\hline To what extent did your & Highly & 0 & 0 & 4 & 8 & 0 & 0 & 4 & 7,27 & & \\
\hline undergraduate education & Partially & 1 & 33,33 & 21 & 42 & 1 & 50 & 23 & 41,82 & * & 0201 \\
\hline affect your musical culture & Very little/few & 2 & 66,67 & 20 & 40 & 0 & 0 & 22 & 40 & &, 291 \\
\hline accumulation? & No & 0 & 0 & 3 & 6 & 0 & 0 & 3 & 5,45 & & \\
\hline & Total & 3 & 100 & 50 & 100 & 2 & 100 & 55 & 100 & & \\
\hline
\end{tabular}


It was determined that there is no statistically significant relationship between education level and music culture accumulation ( $p>0.05)$. Although it is not statistically significant, $66,67 \%$ of those who graduated from college, $58 \%$ of those who graduated from university, $50 \%$ of those who held a master / doctorate degree stated that the music culture accumulation occupied a partial place in their general culture. Also, $66.67 \%$ of college graduates, $60 \%$ of university graduates and $50 \%$ of graduate / doctoral graduates informed that they partially had music culture accumulation. Then $66,67 \%$ of college graduates, $54 \%$ of university graduates and $50 \%$ of graduate / doctoral graduates evaluated their musical culture accumulation in terms of entertainment. Next, $33.33 \%$ of college graduates and $52 \%$ of university graduates mentioned that the behavior of the individual with adequate musical culture may highly influence the general life experience. In addition, $52 \%$ of university graduates and $50 \%$ of graduate / doctoral graduates pointed out that they could partially use the knowledge consciously based on music culture in their life. Additionally, $33.33 \%$ of those who graduated from college and $52 \%$ of those who graduated from university think that the music is highly significant in the individual's life.

It was noticed that there is no statistically significant relationship between the educational level and the involvement in musical activities during the undergraduate studies ( $\mathrm{p}<0.05$ ). $33.33 \%$ of college graduates, $76 \%$ of university graduates and $50 \%$ of graduate / doctoral graduates expressed that they got engaged in musical activities as listeners during their education period. On the other hand, $10 \%$ of the university graduates mentioned that they participated in the choir. $33.33 \%$ of college graduates, $42 \%$ of university graduates, $50 \%$ of graduate / doctoral graduates stated that their undergraduate education partially affected their musical culture accumulation. Also, $100 \%$ of college graduates, $68 \%$ of university graduates and $50 \%$ of graduate / doctoral graduates asserted that they did not take any courses about music culture in higher education. $66,67 \%$ of college graduates, $92 \%$ of university graduates and $100 \%$ of graduate / doctoral graduates remarked that they took music education during undergraduate studies. In addition, 56\% of university graduates, $100 \%$ of graduate / doctoral graduates believed that after the teacher candidates in education faculties take music-related courses, their perspective on musical culture will highly make progress. Moreover, $42 \%$ of university graduates and $50 \%$ of graduate / doctoral graduates reflected that they partially participated in musical activities in Afyonkarahisar city center. $33.33 \%$ of college graduates, $48 \%$ of university graduates, $100 \%$ of graduate / doctoral graduates specified that the city in which they work made partial contribution to their own musical culture.

It was figured out that there is a statistically significant relationship between the level of education and the level of considering music activity sufficient in the place the teachers work $(\mathrm{p}<0,05) .33 .33 \%$ of the college graduates, $48 \%$ of the university graduates and $50 \%$ of the graduate / doctoral graduates think that the music activities organized in the city they work are partially sufficient. $66.67 \%$ of the college graduates and $4 \%$ of the university graduates do not consider the musical activities in the city they work as sufficient.

It was detected that there is a statistically significant relationship between the level of education and the degree of support for music events included in the social activities ( $p<0,05) .66 \%$ of university graduates and $50 \%$ of graduate I doctoral graduates mentioned that the musical events combined with the social activities should be highly supported. On the other hand, $33.33 \%$ of college graduates stated that music activities included in social activities should "not" be supported at all.

It was found out that there is a statistically significant relationship between the level of education and the frequency of obtaining music related publications ( $p$ $<0,05) .36 \%$ of the university graduates and $50 \%$ of graduate / doctoral graduates reported that they partially obtained the music related publications. Additionally, $10 \%$ of the university graduates remarked that they highly obtain music related publications.

$44 \%$ of the university graduates and $50 \%$ of graduate / doctoral graduates reported that they made very little use of these music related publications. Also, $33.33 \%$ of college graduates and $46 \%$ of university graduates indicated that they possessed very few music CD-DVD or record archives. $33.33 \%$ of the college graduates and $62 \%$ of the university graduates think that the role of music culture accumulation is highly important in a contemporary model of teacher. $33.33 \%$ of college graduates, $60 \%$ of university graduates and $50 \%$ of graduate / doctoral graduates reported that having a good music culture will highly affect their own subject fields. $33.33 \%$ of the high school graduates, $32 \%$ of the university graduates and $50 \%$ of the graduate / doctoral graduates mentioned that they partially used music culture accumulations as a tool in their own subject fields. 
Table 24. Chi Square Test Results on the Relationship between Variables Related to Occupational Seniority and Music Culture Accumulations

\begin{tabular}{|c|c|c|c|c|c|c|c|c|c|c|c|c|c|}
\hline & \multicolumn{10}{|c|}{ Seniority in the Profession } & \multicolumn{2}{|c|}{ Chi Square Test } \\
\hline & & \multicolumn{2}{|c|}{$0-5$ years } & \multicolumn{2}{|c|}{$6-10$ years } & \multicolumn{2}{|c|}{$11-15$ years } & \multicolumn{2}{|c|}{16 years and more } & \multicolumn{2}{|c|}{ Total } & \multirow[b]{2}{*}{ Chi Square } & \multirow[b]{2}{*}{$\mathrm{p}$} \\
\hline & & $\mathrm{n}$ & $\%$ & $\mathrm{n}$ & $\%$ & $\mathrm{n}$ & $\%$ & $\mathrm{n}$ & $\%$ & $\mathrm{n}$ & $\%$ & & \\
\hline \multirow{5}{*}{$\begin{array}{l}\text { As you evaluate it in } \\
\text { your general culture, } \\
\text { what is the position of } \\
\text { your music culture } \\
\text { accumulation? }\end{array}$} & Completely & 2 & 22,22 & 1 & 3,7 & 1 & 14,29 & 1 & 8,33 & 5 & 9,09 & \multirow{5}{*}{$*$} & \multirow{5}{*}{0,384} \\
\hline & Highly & 2 & 22,22 & 7 & 25,93 & 1 & 14,29 & 4 & 33,33 & 14 & 25,45 & & \\
\hline & Partially & 5 & 55,56 & 18 & 66,67 & 3 & 42,86 & 6 & 50 & 32 & 58,18 & & \\
\hline & Very little/few & 0 & 0 & 1 & 3,7 & 2 & 28,57 & 1 & 8,33 & 4 & 7,27 & & \\
\hline & Total & 9 & 100 & 27 & 100 & 7 & 100 & 12 & 100 & 55 & 100 & & \\
\hline \multirow{5}{*}{$\begin{array}{l}\text { To what extent do you } \\
\text { think you have music } \\
\text { culture accumulation? }\end{array}$} & Completely & 2 & 22,22 & 1 & 3,7 & 1 & 14,29 & 1 & 8,33 & 5 & 9,09 & \multirow{5}{*}{$*$} & \multirow{5}{*}{0,345} \\
\hline & Highly & 2 & 22,22 & 6 & 22,22 & 1 & 14,29 & 4 & 33,33 & 13 & 23,64 & & \\
\hline & Partially & 5 & 55,56 & 19 & 70,37 & 3 & 42,86 & 6 & 50 & 33 & 60 & & \\
\hline & Very little/few & 0 & 0 & 1 & 3,7 & 2 & 28,57 & 1 & 8,33 & 4 & 7,27 & & \\
\hline & Total & 9 & 100 & 27 & 100 & 7 & 100 & 12 & 100 & 55 & 100 & & \\
\hline \multirow{5}{*}{$\begin{array}{c}\text { In which dimension do } \\
\text { you evaluate your music } \\
\text { culture accumulations } \\
\text { more? }\end{array}$} & Artistic & 2 & 22,22 & 7 & 25,93 & 3 & 42,86 & 5 & 41,67 & 17 & 30,91 & \multirow{5}{*}{$*$} & \multirow{5}{*}{0,509} \\
\hline & Scientific & 0 & 0 & 1 & 3,7 & 0 & 0 & 2 & 16,67 & 3 & 5,45 & & \\
\hline & Entertainment & 6 & 66,67 & 15 & 55,56 & 4 & 57,14 & 5 & 41,67 & 30 & 54,55 & & \\
\hline & Other & 1 & 11,11 & 4 & 14,81 & 0 & 0 & 0 & 0 & 5 & 9,09 & & \\
\hline & Total & 9 & 100 & 27 & 100 & 7 & 100 & 12 & 100 & 55 & 100 & & \\
\hline \multirow{4}{*}{\begin{tabular}{|c|} 
To what extent do you \\
believe that the behavior \\
of an individual with \\
enough musical cultures \\
affects his or her overall \\
life experience? \\
\end{tabular}} & Completely & 2 & 22,22 & 2 & 7,41 & 1 & 14,29 & 3 & 25 & 8 & 14,55 & \multirow{4}{*}{$*$} & \multirow{4}{*}{0,481} \\
\hline & Highly & 2 & 22,22 & 16 & 59,26 & 3 & 42,86 & 6 & 50 & 27 & 49,09 & & \\
\hline & Partially & 5 & 55,56 & 9 & 33,33 & 3 & 42,86 & 3 & 25 & 20 & 36,36 & & \\
\hline & Total & 9 & 100 & 27 & 100 & 7 & 100 & 12 & 100 & 55 & 100 & & \\
\hline & Completely & 0 & 0 & 2 & 7,41 & 1 & 14,29 & 1 & 8,33 & 4 & 7,27 & & \\
\hline Do you consciously use & Highly & 4 & 44,44 & 8 & 29,63 & 1 & 14,29 & 5 & 41,67 & 18 & 32,73 & & \\
\hline $\begin{array}{l}\text { your knowledge in your } \\
\text { life based on your music }\end{array}$ & Partially & 4 & 44,44 & 14 & 51,85 & 4 & 57,14 & 5 & 41,67 & 27 & 49,09 & * & 0,983 \\
\hline culture? & Very little/few & 1 & 11,11 & 3 & 11,11 & 1 & 14,29 & 1 & 8,33 & 6 & 10,91 & & \\
\hline & Total & 9 & 100 & 27 & 100 & 7 & 100 & 12 & 100 & 55 & 100 & & \\
\hline & Completely & 2 & 22,22 & 3 & 11,11 & 1 & 14,29 & 2 & 16,67 & 8 & 14,55 & & \\
\hline To what extent do you & Highly & 4 & 44,44 & 14 & 51,85 & 2 & 28,57 & 7 & 58,33 & 27 & 49,09 & * & \\
\hline $\begin{array}{c}\text { think music is important } \\
\text { in an individual's life? }\end{array}$ & Partially & 3 & 33,33 & 10 & 37,04 & 4 & 57,14 & 3 & 25 & 20 & 36,36 & & 0,86 \\
\hline & Total & 9 & 100 & 27 & 100 & 7 & 100 & 12 & 100 & 55 & 100 & & \\
\hline & As an audience & 8 & 88,89 & 17 & 62,96 & 6 & 85,71 & 9 & 75 & 40 & 72,73 & & \\
\hline Which musical activities & Joining a chorus & 0 & 0 & 3 & 11,11 & 0 & 0 & 2 & 16,67 & 5 & 9,09 & & \\
\hline $\begin{array}{c}\text { were you involved in } \\
\text { during your }\end{array}$ & Instrument playing & 0 & 0 & 4 & 14,81 & 1 & 14,29 & 0 & 0 & 5 & 9,09 & * & 0,678 \\
\hline undergraduate studies? & Other & 1 & 11,11 & 3 & 11,11 & 0 & 0 & 1 & 8,33 & 5 & 9,09 & & \\
\hline & Total & 9 & 100 & 27 & 100 & 7 & 100 & 12 & 100 & 55 & 100 & & \\
\hline & Completely & 0 & 0 & 1 & 3,7 & 1 & 14,29 & 1 & 8,33 & 3 & 5,45 & & \\
\hline & Highly & 2 & 22,22 & 1 & 3,7 & 1 & 14,29 & 0 & 0 & 4 & 7,27 & & \\
\hline undergraduate education & Partially & 3 & 33,33 & 13 & 48,15 & 1 & 14,29 & 6 & 50 & 23 & 41,82 & & \\
\hline affect your musical & Very little/few & 2 & 22,22 & 12 & 44,44 & 4 & 57,14 & 4 & 33,33 & 22 & 40 & r & , \\
\hline & No & 2 & 22,22 & 0 & 0 & 0 & 0 & 1 & 8,33 & 3 & 5,45 & & \\
\hline & Total & 9 & 100 & 27 & 100 & 7 & 100 & 12 & 100 & 55 & 100 & & \\
\hline
\end{tabular}

It was detected that there is no statistically significant relationship between seniority in the profession and musical culture accumulations ( $\mathrm{p}>0.05)$. Although there seems to be no statistically significance, $55.56 \%$ of the 
teachers whose seniority in the profession is between $0-5$ years, $66.67 \%$ of those whose seniority in the profession is between $6-10$ years, $42.86 \%$ of those whose seniority in the profession is between $11-15$ years and $50 \%$ of those whose seniority in the profession is 16 years and more believed that the music culture accumulation held a partial position in their general culture. Also, $55.56 \%$ of the teachers whose seniority in the profession is between $0-5$ years, $70.37 \%$ of those whose seniority in the profession is between 6-10 years, $42.86 \%$ of those whose seniority in the profession is between $11-15$ years and $50 \%$ of those whose seniority in the profession is 16 years and more stated that they partially owned music culture accumulation. In addition, $66.67 \%$ of the teachers whose seniority in the profession is between $0-5$ years, $55.56 \%$ of those whose seniority in the profession is between $6-10$ years, $57.14 \%$ of those whose seniority in the profession is between $11-15$ years and $41.67 \%$ of those whose seniority in the profession is between 16 years and more pointed out that they evaluated their music culture accumulation in terms of entertainment. Additionally, $22.22 \%$ of those with $0-5$ years of professional seniority, $59.26 \%$ of those with $6-10$ years of professional seniority, $42.86 \%$ of those with $11-15$ years of professional seniority and $50 \%$ of those with more than 16 years of professional seniority specified that the behavior of the individual with adequate musical culture may highly influence the general life experience. Moreover, $44.44 \%$ of those with professional seniority of $0-5$ years, $51.85 \%$ of those with professional seniority of $6-10$ years, $57.14 \%$ of those with professional seniority of $11-15$ years and $41.67 \%$ of those with professional seniority of 16 years and more implied that they partially used the knowledge consciously based on music culture in their life. Furthermore, 44.44\% of the teachers whose seniority in the profession is between $0-5$ years, $51.85 \%$ of those whose seniority in the profession is $6-10$ years, $28.57 \%$ of those whose seniority in the profession is $11-15$ years and $58.33 \%$ of those whose seniority in the profession is 16 years and more remarked that music is highly significant in the individual's life. $88.89 \%$ of those with $0-5$ years of professional seniority, $62.96 \%$ of those with $6-10$ years of professional seniority, $85.71 \%$ of those with $11-15$ years of professional seniority and $75 \%$ of those with more than 16 years of professional seniority worded that they participated in musical activities as an audience in their undergraduate studies. Another finding is that $33.33 \%$ of the teachers whose seniority in the profession is between $0-5$ years, $48.15 \%$ of those whose seniority in the profession is between $6-10$ years, $14.29 \%$ of those whose seniority in the profession is between 11-15 years and $50 \%$ of those whose seniority in the profession is 16 years and more reflected that their undergraduate education partially influenced their music culture accumulation. $55.56 \%$ of those with $0-5$ years of professional seniority, $74.07 \%$ of those with $6-10$ years of professional seniority, $42.86 \%$ of those with $11-15$ years of professional seniority and $83.33 \%$ of those with more than
16 years of professional seniority expressed that they did not take any courses related to music culture in higher education. What is more, $88.89 \%$ o of the teachers whose seniority in the profession is between $0-5$ years, $88.89 \%$ of those whose seniority in the profession is between 6-10 years, $100 \%$ of those whose seniority in the profession is between $11-15$ years and $91.67 \%$ of those whose seniority in the profession is 16 years and more rendered that they took music education during their undergraduate studies. $33.33 \%$ of those with $0-5$ years of professional seniority, $62.96 \%$ of those with 6-10 years of professional seniority, $57.14 \%$ of those with $11-15$ years of professional seniority and $50 \%$ of those with more than 16 years of professional seniority stated that after the candidate teachers take courses related with musical culture in the education faculties, their viewpoints on the musical culture may highly develop. $33.33 \%$ of the teachers whose seniority in the profession is between $0-5$ years, $33.33 \%$ of those whose seniority in the profession is between $6-10$ years, $57.14 \%$ of those whose seniority in the profession is between 11-15 years and $50 \%$ of those whose seniority in the profession is more than 16 years explained that they partially participated in musical events taking place in Afyonkarahisar city center. $66.67 \%$ of those with $0-5$ years of professional seniority, $44.44 \%$ of those with $6-10$ years of professional seniority, $42.86 \%$ of those with $11-15$ years of professional seniority and $50 \%$ of those with more than 16 years of professional seniority believed that the city in which they work made partial contribution to their own musical culture. $55.56 \%$ of the teachers with a professional seniority of $0-5$ years, $44.44 \%$ of those with a professional seniority of 6-10 years, $57.14 \%$ of those with a professional seniority of $11-15$ years and $41.67 \%$ of those with a professional seniority more than 16 years considered the musical activities taking place in the city they work as partially sufficient. $55.56 \%$ of the teachers with a professional seniority of $0-5$ years, $55.56 \%$ of those with a professional seniority of $6-10$ years, $71.43 \%$ of those with a professional seniority of $11-15$ years and $75 \%$ of those with a professional seniority more than 16 years reflected that the musical activities covered in social activities should be highly supported. It was also found out that $44.44 \%$ of the teachers whose seniority in the profession is between $0-5$ years, $37.04 \%$ of those whose seniority in the profession is between 6-10 years, $28.57 \%$ of those whose seniority in the profession is between $11-15$ years and $25 \%$ of those whose seniority in the profession is 16 years and more indicated that they partially obtained publications related to music. $33.33 \%$ of the teachers with a professional seniority of $0-5$ years, $40.74 \%$ of the teachers with a professional seniority of $6-10$ years, $57.14 \%$ of the teachers with a professional seniority of $11-15$ years and $41.67 \%$ of the teachers with a professional seniority of 16 years and more specified that they made very little use of these publications. $33.33 \%$ of the teachers whose seniority in the profession is between $0-5$ years, $40.74 \%$ of those whose seniority in the 
profession is between $6-10$ years, $57.14 \%$ of those whose seniority in the profession is between $11-15$ years and $50 \%$ of those whose seniority in the profession is 16 years or more predicated that they had very few music-related CD-DVD or record archives.. $44.44 \%$ of the teachers with a professional seniority of $0-5$ years, $59.26 \%$ of those with a professional seniority of 6-10 years, $42.86 \%$ of those with a professional seniority of $11-15$ years and $75 \%$ of those with a professional seniority 16 years and more pointed out that the role of music culture accumulation is highly significant in a modern teacher model. $66.67 \%$ of the teachers whose seniority in the profession is between $0-5$ years, $55.56 \%$ of those whose seniority in the profession is between $6-10$ years, $28.57 \%$ of those whose seniority in the profession is between $11-15$ years and $75 \%$ of those whose seniority in the profession is between 16 years and more believed that having a good music culture may highly influence their own subject fields. Finally, $44.44 \%$ of the teachers whose seniority in the profession is between 6-10 years, $42.86 \%$ of those whose seniority in the profession is between $11-15$ years and $25 \%$ of those whose seniority in the profession is 16 years and more mentioned that they partially used their music culture accumulation as a tool in their own subject field.

\section{The Other Results about Preschool Teachers Concerning the Subject (Requires Minor Revision: Direct quotations in section 4 must be enclosed in quotation marks.)}

These views are listed in terms of:

"The music activities in Afyon province should be more active and the musical courses should be generalized to be able to play a musical instrument."

"The kids are moving and full of energy. I believe that it's a good way to draw their attention. If music lessons in education are as important as a mathematics lesson, then music may reach its essential value. More seminars can be organized so that we can improve ourselves in the music field.

"The contribution of my city to music culture in which I work is not enough so that they are weak about activities such as necessary publicity and information."

"Both the province and the school we are in must be intensively and effectively involved in activities supporting music culture."

"Within the scope of in-service training, it will be very useful to give "Orff" education to pre-school teachers or to train them to use the instrument to be used in teaching children's songs in class."

"Music education and music culture should be support via in-service training. "

"The music education course during the undergraduate period should be extended over to 4 years and there should be theoretical and practical courses for music culture. Additionally, music culture should be directed in the context of in-service training."

"During the music education in the undergraduate period, music culture should be valued and music courses should be included in and extended to 4 years education."

"The music education course taken during the undergraduate period should not be limited to only theoretical knowledge and block flute. There must be theoretical and practical lessons to support musical culture."

"During the undergraduate period, music education should not only be covering theoretical education and playing block flute. I think block flute is not a suitable instrument in the training of preschool education."

"Since we only took theoretical music course in the undergraduate period and the duration of the course was not enough, its contribution in terms of music culture has been minimal."

"There should be a quality archive for music culture. "

"I do not find it suitable to have theoretical education in the form of a seminar. Seminars should be given to the teachers by the experts through practicing them, by living and teaching them. If so, I believe it will be more efficient."

"Courses related to music culture are not included in undergraduate education curriculum. We must learn to play a proper instrument, solfege, and also learn the songs about our field and must have a complete education. In addition, music culture courses should also be added."

"For pre-school education, it is essential that attendance of music teachers, especially in kindergartens classes at school, should be ensured. The institution I work for should have an archive of music culture."

"We, as being pre-school teachers, should be given in-service training seminars on music education and culture and we must have an archive to utilize."

\section{Conclusions, Discussion and Suggestions}

The preschool teachers stated that they partially own music culture accumulation with $58,18 \%$ while $25,45 \%$ of the preschool teachers believe that they highly have music culture accumulation. "No" option has been left blank. This state shows that most of the teachers think that they have a certain musical culture within their general cultures, even if it is partial. However, the quality of their musical culture accumulation should be evaluated according to how they were educated during the undergraduate period. The preschool teachers mentioned that they partially own music culture accumulation with $60 \%$, highly with $23,64 \%$, completely with $9,09 \%$ and very little with $7,27 \%$, respectively. The last option has been unmarked. In this case, it appears that the teachers think that they have a certain amount of music culture accumulation, even if it is partial. It was indicated that the preschool teachers regard 
musicals an entertainment tool with $54.55 \%$ while $30,91 \%$ of the teachers consider it as an art. It is not a positive situation for preschool teachers to regard music as merely an entertainment medium. Music is not just for fun and listening. It is in a state of being intertwined with culture. In this scope, it can be commented that in addition to music education provided to preschool teacher candidates in their undergraduate education period. If they participate in workshops about music culture, conferences and in-service trainings on music culture and music education and take part in activities such as courses, this situation can change their perspectives in a more qualified and conscious way in terms of their musical culture.

Preschool teachers have indicated that the behavior of an individual with enough musical culture influences his overall life greatly, which is highly with $49,09 \%$, partially with $36,36 \%$ and completely with $14,55 \%$, respectively. In this case, the majority of teachers are of the opinion that having musical culture affects the general life of the individual to a great extent. Also, the "very little" and "no" options were left blank and unmarked. It turned out that the preschool teachers use their music culture accumulations partly in their lives and they could not use these accumulations qualitatively and consciously in their lives. Also, the "completely" option has not been marked and left blank. $49,09 \%$ of the respondents think that music has a highly important place in the life of the individual while $36,36 \%$ of the respondents think that music has a partially important part as well as $14,55 \%$ of the respondents think that music has a "completely" important part. Thus, it may be concluded for a large majority of preschool teachers that music has an important place in the life of the individuals. This is a positive result on the dimension of awareness. This study reveals that most of the preschool teachers who participated in the research cannot participate in the music events in Afyonkarahisar. The respondents marked "no" option with $21.82 \%$, very little option with $30.91 \%$ and partially option with $40 \%$, respectively. Therefore, in-service training courses and activities should be increased in the city center where the pre-school teachers work, and musical activities related to music culture should be organized in cooperation with city-university. In this context, municipalities, governorships, provincial directorate of national education, teachers' institutions and universities have great responsibilities. It is clear that jazz, new age and classical western music are not preferred at all. In this framework, in order to introduce preschool teachers with types of music of their own culture as well as universal musical genres, in - service training seminars, concerts and workshops should be organized between university-national education and university-city cooperation. The preschool teachers, during their undergraduate education period, indicated that they attended to musical activities as audiences with $72,73 \%$. The individuals who love to listen to music but who do not consciously have a music culture and who do not/cannot use this music culture in their daily life and academic field cannot understand and perceive music sufficiently. As a matter of fact, music is not just for listening. Music is not a thing of its own. On the other hand, it is an important part of culture and it is something to which individuals add meaning. Therefore, musical activities related to musical culture and related media during the undergraduate education period should be presented to the preschool teacher candidates more and in a more qualified way. In this context, as the table shows, the lack and weakness of these environments can be seen. It is clear that teachers' undergraduate education has a very low effect on music culture accumulation by $69,09 \%$.Having "No" option with $69,09 \%$, it was observed that preschool teachers find the course duration and content of the music education course in undergraduate education insufficient and believe that the lack of a music culture course is an obvious shortcoming. The preschool teachers request that music education courses be reviewed and re-organized and music culture course be added to curriculum. As for the music education course in their undergraduate education period, it is seen that preschool teachers participating in the study have taken only theoretical training with $54 \%$ and block flute training with $54 \%$. In this case, music education courses at universities for preschool teachers should not be limited to two semesters, and qualified changes and arrangements should be made. The teachers participated in the study agreed on the viewpoint the musical cultures of preschool education candidate teachers who take music-related courses in their undergraduate studies may develop highlywith $54,55 \%$, partially with $29,09 \%$, completely with $10,91 \%$, respectively. This is actually a positive result in the dimension of awareness. The preschool teachers who took part in the study agreed on the opinion that if they take courses related to music in undergraduate period, the music cultures of prospective preschool teachers will develop. This is actually appositive result in terms of awareness dimension. It is seen that most of the pre-school teachers who participated in the research were unable to participate in the music events in Afyonkarahisar. "No" option with $21.82 \%$, very little/few option with $30.91 \%$ and partially options with $40 \%$ have been marked. In this case, in-service training courses and activities should be increased in the city center where the pre-school teachers work, and musical activities related to music culture should be held in cooperation with the city and university. In this context, it is necessary for municipalities, governorships, provincial directorate of national education, teachers' institutions and universities to carry out serious duties. It is observed that the provinces where the pre-school teachers worked have not contributed to their musical culture; which is partially with $49,09 \%$, very little with $34,55 \%$ and no with $9,09 \%$. This state suggests that the available opportunities in Afyonkarahisar province center for teachers to develop themselves in terms of musical culture accumulations are partially sufficient. It is seen that pre-school teachers who participated in the research have obtained music publications with a very low 
rate of $34,55 \%$, and $34.55 \%$ of the pre-school teachers expressed that they partially have obtained music publications. Setting off with the findings, it is possible to say that nearly half of the preschool teachers participating in the study have very few chances of obtaining music-related publications. In this scope, music seminars and activities to introduce related publications in Afyonkarahisar province should be performed for preschool teachers. Besides, archives including music-related publications can be provided by school administrators, which may serve as a qualified resource. Such publications can be included in the Afyonkarahisar provincial library, which can make teachers well-equipped about music education and culture. $43,64 \%$ of the teachers who participated in the study stated that they have very few CD-DVD and / or record archives related to music while $27.27 \%$ of the teachers partially have CD-DVD and / or record archives related to music. According to this data, it can be concluded that the teachers do not have a qualified and adequate music archive. As we go through the table, it was determined that the pre-school teachers could not realize the importance of creating music archives. The pre-school teachers stated that they never used music culture accumulation in their fields with $24.13 \%$ and very little with $36.78 \%$. In this case, it was determined that the majority of the teachers could not consciously apply the music-related information into their own subject fields.

It was determined that there is no statistically significant relationship between gender and musical culture accumulation. In this scope, it was observed that there is no difference in the viewpoints of preschool teachers regarding their music culture levels, their attitudes towards music and their attitudes towards music art in terms of gender variable. It can be deduced that the other factors play a bigger role rather than the gender variable in the formation of the music culture of the individual.

There is no statistically significant relationship between education level and musical culture accumulation as it was the case in the gender variable. In this context, when the education level of the preschool teachers is taken into consideration, it is seen that there is no significant difference in the level of teachers' musical culture. It can be inferred from this result that regardless of the education level that teachers have, it does not have a positive impact on their musical cultures or teachers do not personally develop themselves in this respect. Here it can be commented that deficiencies and problems related to music culture and music education in the education system should be re-examined.

As the issue is approached in terms of professional seniority variable, it is noticed that there has not been a change in the level of teachers' musical culture. In general, the scores of the groups are close to each other and no significant differences have been detected. There is no statistically significant relationship between the place of work and the musical culture accumulations. This state displays result that the possibilities available for the teachers in Afyonkarahisar city center to develop themselves in terms of musical culture accumulation are partially sufficient.

According to the results of unpublished master's thesis of Akın (2017) named as "The Music Culture of Branch Teachers working in the Educational Institutions at the Secondary Education Level: The Case of Sivas Province", it has been understood that the music culture levels of secondary education branch teachers are not very good at all. It was concluded that no differences have been observed in terms of music culture in the five other variables apart from the two sub-problems of the research. It was also reported that the majority of the teachers did not or could not allocate much time in the daily life to the music or they regarded music just as a fun activity, a means of spending time.

In the unpublished master's thesis of Arabac1 (2010) titled as "Interviews of Muslims" Opinions of Different Field Teachers on Musical Culture working in Şereflikoçhisar and Evren County", literature review method was adopted and a questionnaire has been applied to examine the opinions of teachers about their music culture. According to the results obtained from the research, it was reported that teachers do not consciously evaluate their musical culture accumulations, do not make use of music culture in their own fields and they do not find activities enough related to music in the places where they work.

It was found out that no different results between the results of this study and the related researches in the literature have been achieved. In this context, this study has shown that a significant number of preschool teachers do not consider music education courses at undergraduate level satisfactory, and preschool teachers request that music education courses are reviewed and re-organized and music culture course are added to the curriculum. At the same time, the majority of them are in need of music education, in-service training related to music culture and a qualified archive. Moreover, it can be said that the music culture levels of the preschool teachers are not very good. It was concluded that the majority of preschool teachers do not spend much time on music in their daily lives and they regard music just as a means of listening, entertainment, and leisure time activity.

\section{Suggestions}

Musical education should be upgraded as a qualification in teacher education institutions. Musical events (concerts, auditions, seminars, interviews) that will raise the level of music culture of preschool teachers should be held frequently, and prospective teachers should be actively involved in such activities. Music education should be given by those who are experts in this field. With the support and supervision of experts in the field of music education, teacher choirs should be formed and concerts should be held throughout the province. 
The music education courses taken during the undergraduate period should not be limited to only theoretical knowledge and block flute. The music education course, which is included in the curriculums of the department of preschool education in the education faculties, should be re-examined, and the curriculums should be organized in such a way as to improve the musical culture accumulation of the teacher candidates. As a matter of fact, the music education that is included in the pre-school teaching curriculum should be provided to them within the compulsory courses for 4 years in order for the pre-school teacher candidates in department of preschool education to develop their musical culture. All teacher candidates should learn to play at least one instrument at a sufficient level during the four years of music education and should also participate regularly in various music events outside the school.

Having started working, it is necessary for the preschool teachers to improve themselves in terms of music education and music culture and to renew themselves. In this context, in-service training activities for music education and music culture should be provided to preschool teachers and the participation of preschool teachers in in-service courses, seminars etc. should be encouraged by the Ministry of National Education, the Provincial Directorate of National Education and the institutions who the preschool teachers work for. Thus, their participation in those activities should be ensured.

In order to introduce preschool teachers with types of music of their own culture as well as universal musical genres, in - service training seminars, concerts and workshops should be organized between university national education and university - city cooperation. A qualified archive should be arranged with the help of both universal music culture accumulation and national music culture. During the preparation of the music education course in the preschool curriculum today's conditions should be considered in addition to the opinions and expectations of the preschool teachers and experts in the field of music education so that a teaching program meeting the needs may be ensured. A program to be created in this axis will help to achieve a more effective music education in the field of preschool education and will have an impact on the musical cultures of preschool teachers. The administrators of preschool teachers should actively take part in the realization of effective music education and in the formation of music culture, and they should supply support with the preschool teachers. Musical events (concerts, auditions, seminars, and interviews) should be held frequently, and active participation of the teacher candidates should be ensured.

\section{REFERENCES}

[1] Günay, E. (2011). Music Sociology - A General Look on Music Culture from Sociology (2nd Edition). Istanbul: Bağlam Publishing.

[2] Eliot, T. S. (1981). Thoughts on Culture. (Translated by Sevim Kantarcioğlu). Ankara: Ministry of Culture Publications.

[3] Ünver, E. (2012). "Art and Society". Journal of Science and Technology.

[4] Say, A. (2008). What is music? What kind of Art is it? İstanbul: Evrensel Publishing House.

[5] Birol, K. B. (2002). "The Relationship between Social Structure and Cultural and Musical Development". Symposium in Turkey. Ankara: Sevda Cenap and Foundation Publications.

[6] Artut, Kazım (2001). Arts Education. Ankara: Anı Publishing.

[7] Uçan, A. (1993). Music Education. Ankara: Music Encyclopedia Publications.

[8] Mcclary, S. (2007)."Reshaping a Discipline", Dance Music Culture towards Folklore. Istanbul: Boğaziçi University Publishing House.

[9] Uçan, A.(2005). Turkish Music Culture. Ankara: Önder Publishing House.

[10] Khan, S. I. (1994). The Bridge between Music, Man and the Universe, Istanbul: Aritan Publishing House.

[11] Öz, Nesrin,B. (2001), “The Importance of Music Education in Cultural Change of Human”, Uludag University Journal of Education Faculty Journal, Volume: XIV, Issue: 1, Bursa.

[12] Günay, E. (2006). Music Sociology. Istanbul: Bağlam Publishing.

[13] Cook, N. (1999). ABC of Music.(First edition). Istanbul: Kabalcı Publishing House.

[14] Kurbanov, B. (2005). Some artistic-aesthetic problems of music (First edition) .Ankara: Aktif Publishing House.

[15] Şenel, Onur (2014)."The Complex Background of Music Choice".Journal of International Social Research. Volume 7, Issue 30, p: 213-227.

[16] Say, A. (2007). Music Writings. (First edition). Ankara: Music Encyclopedia Publications.

[17] Arabac1, M. (2010). Views of Teachers about Music Culture Working in Şereflikoçhisar and Evren Counties. Unpublished Master's Thesis, Gazi University Institute of Educational Sciences.

\footnotetext{
* This study has been presented as an oral representation paper 3rd International Conference on Lifelong Education and Leadership in Polytechnic University of Porto, PORTUGAL, 12-14 September, 2017.
} 